\title{
Cassava as Ambiguous Plants: Study of the Role of Cassava in Java Island in the Colonial Period
}

\author{
${ }^{1}$ Haryono Rinardi, ${ }^{2}$ Sutedjo K. Widodo \\ $\left\{{ }^{1}\right.$ rinardiharyono@yahoo.com; ${ }^{2}$ sutejokw@yahoo.com $\}$ \\ Department of History, Faculty of Humanities, Diponegoro University \\ Jl. Prof. Soedarto, Tembalang, Semarang, 50275, Indonesia
}

\begin{abstract}
This paper entitled Cassava as Ambiguous Plants: Study of the Role of Cassava in Java Island in the Colonial Period using the historical method in the preparation. This paper discusses the role and benefits of cassava in Java during the colonial period. This paper reveals that cassava is useful as a trading crop and as a food crop during the colonial period. That situation then made the plant known as an ambiguous plant, because it has a dual role. This is an interesting finding because basically plants only have one benefit, namely whether they are trading crops or food.
\end{abstract}

Keywords: Cassava; food crops; trade plants.

\section{Introduction}

Studies of the history of agriculture and plantations in Indonesia have been carried out, both macro [1] [2] as well as those study agricultural development and policy in Indonesia as done by Pierre van der Eng [3] and Booth [4]. Local studies, especially on plantation crops, can also be found, for example about tobacco [5] and sugar cane with the sugar industry [6]. Studies on plantation crops, which are of a macro nature but only specifically discuss one plant, are many, for example about rubber [7], sugar cane [2] coffee [8], oil palm [9], rubber [10].

The study of the history of agriculture is interesting because, in its development on Java island, plants were found that they had ambiguous properties. Meaning, the plant functions not only as a trading plant but also as a food crop. The plant is cassava which was originally a trading plant because it was exported to the various country in the colonial era [11]. On the other hand, cassava serves as a food crop on Java Island, especially when facing the 1930s malaise. Cassava is the most important alternative food crop in Java island and Madura. This condition continued until entering the period of Indonesian independence. Although cassava had experienced a sharp decline in production during the independence war, gradually, the production rate continued to increase and then exceeded 8 million tons since 1959. The interesting thing is that the cassava production rate was only defeated by rice, which always produces a harvest of over 8 million tons/year except in the 1950-1952 period. This situation shows that cassava is the second most important food crop in Java island and Madura from the colonial period to the beginning of independence. Cassava, although it has only developed widely in Java and Madura in the early twentieth century, its role and benefits are very large for the population of Java and Madura, even Indonesia.

This article tries to examine how the role and benefits of cassava in the colonial period. Cassava is different from other plants, because of its ambiguous nature. Thus, this discussion 
tries to explain how cassava grows and develops on the island of Java in the colonial period, then how it acts as a food crop and trading crop.

\section{Method}

This article is a study about history economy, specifically the development of cultivation and the export cassava on Java for future early XX century. The method that is used is method history which goes in some stages. First is known as a heuristic, that is the process of searching and collect sources history, both primary and secondary related with writing this paper. On the first stage, that is also a second stage, that is criticisms made with paying attention to any statements in the source of history. It is very important to write this paper because of various statistical data should be enforced in a careful manner, even need to do koroborasi, i.e. compare the two sources with the principal of the same problem.

Some important sources which are used in writing are; Koloniaal Verslag which was then continued by Indisch Verslag and Statistich Jaaroverzich van Nederlandsch-Indie. The Jaaroverzich van Nederlandsch-Indie statistics is a source that contains statistical data, including social-economic problems in the Dutch East Indies. While Koloniaal and Indisch Verslag contain qualitative data. Another important source is Economisch Weekblad, which is a weekly main agenda of economic development in the Dutch East Indies. Therefore, the development of cassava problems from an economic point of view is in there. The export statistics for cassava products and their destination countries are in the Statistical Pocket Book of Indonesia. This source is important for understanding the dynamics of cassava on Java during the colonial period.

After heuristics and criticism, an understanding of the facts will be obtained. There are several things that can be obtained at this stage. First, do the periodization and mapping of the development of cassava cultivation in Java. Secondly, on the basis of the first issue, the information about the drivers of the spread of cassava cultivation in Java during the colonial period can be seen. The last stage is historiography or the process of compiling data into systematic writing so that it can be understood as scientific writing.

\section{Results and Discussion}

\subsection{Cassava as a Trading Commodities}

Cassava is originally known as a trading plant. Cassava is cultivated by plantation companies in East Sumatra for export, although there are not many in number. Moreover, the number that continues to decline every year. In the international trade of cassava, especially cassava products (gaplek), Indonesia or precisely Java island and Madura play an important role. This position was held since the 1920s. Other exporting countries are not significant competitors in the international trade of cassava, except Malaya for processed tapioca products. Products from competing countries are still too small to threaten Indonesia's position in the international cassava trade. Therefore, it is not surprising that Indonesia is the largest exporter of cassava and cassava flour in the world [11]. The number of exports of cassava and Indonesian cassava flour, despite showing fluctuations, but the numbers remain high. After experiencing a decline in exports since 1932, exports of cassava and cassava flour increased again starting in 1935. Exports of cassava and cassava flour increased to nearly 200,000 tons in 1937. This was due to the decline in corn production in Europe, cassava and cassava flour were used as food 
ingredients livestock in these countries. Therefore, when corn production in Europe returns to normal, the export of cassava and Indonesian cassava flour dropped. This happened in 1938, so exports of cassava and cassava flour only ranged from 89,000 tons [12]. In this case, there is a connection between the export of cassava \& Indonesian cassava flour and livestock feed supplies and corn prices in Europe. The abundance of livestock feed supplies and the decrease in corn prices in Europe indirectly contributed to the decline in exports of Indonesian cassava and cassava products [12].

Indonesia's position, or rather Java island and Madura as the main exporters of cassava and cassava flour also apply to tapioca flour. Indonesia was the main exporter of tapioca flour in the early twentieth century. The position was held since 1920. The amount of tapioca flour exported by Indonesia was stable during the period 1925-1935, which ranged from 60,000100,000 tons, with the exception of 1928 which reached more than 125,000 tons [11]. The main destination country for tapioca flour exports is the United States. The average export of Indonesian tapioca flour to the United States in the period 1935-1940 reached 129,132 tons [12]

There was a significant surge in exports in 1937, this was due to a shortage of starch products in Europe and America [12]. The opposite condition occurred a year later, the reduced consumption of American tapioca flour became the fall in exports of tapioca flour to the country. This situation was exacerbated by the low price of cassava in the early and mid-1938s. This made farmers postpone most of their harvest, waiting for better prices [12]. The opposite condition occurred in 1938, where the improvement in the price of tapioca flour especially the quality of AA from f4-f5/quintal to $\mathrm{f} 7,48$ /quintal because of the high demand of the United States and Europe [13] has increased the export of Indonesian tapioca flour. Fluctuations in tapioca flour exports returned the following year. The increase of the tapioca flour exports in 1939, in fact, experienced a decline in 1940. This was due to the low demand of the United States, due to rumors that there was a shortage of cassava in Java [12]. Other factors are; First, Dominican emerged as one of the countries that exported tapioca flour to the United States. Second, the decline in demand for imports of tapioca flour from China due to lack of foreign exchange. Third, increased demand for cassava in the domestic market [12].

\subsection{Cassava as a Food Plant}

The population of Java island has only just begun to recognize the benefits of cassava as food in the early twentieth century .During the first twenty years of the twentieth century, cassava was developed as a substitute for food for the indigenous population. New cassava was used as food for the population of Java island in the early twentieth century because of the scarcity of food, as a result of plant pest attacks and long dry seasons. This condition was not favorable for rice harvesting [14]. One reason is that cassava was used as food-related to economic backgrounds.

The population of Java island, in some places, consumes cassava more than rice. The population's need to consume cassava during the period 1913-1920 was quite high. It can be seen from the increasing expansion of cassava cultivation during this period. In general, during the early twentieth century, cassava on Java Island as food could be classified into three groups, when viewed from its role.

One interesting thing about the relation between the price of rice/corn and cassava is that the price of cassava will increase if the prices of these two (rice and corn) are rising. On the other hand, the price will go down if the price of rice and corn has dropped. The phenomenon of 1930 clearly showed it. In the early 1930s, the price of cassava surged due to the high 
consumption of the population. Such conditions are caused by a decrease in food supplies, such as rice and corn. As a result, the prices of both foods increased. However, when the stock of rice and corn recovered at the end of the year so that the prices of the two food items returned to normal, then the price of cassava went down because the demand returned to normal. The same conditions apply in 1935. The long dry season that occurred in 1935 resulted in the rise of the rice prices [14]. The situation caused the indigenous population to switch to making cassava as food. Based on data, consumption of cassava per capita increased from $123 \mathrm{~kg} / \mathrm{capita}$ in 1934 to $132 \mathrm{~kg} /$ capita in 1935 [12]. This caused the price of cassava to rise compared to before.

Based on the above conditions, it can be concluded that the consumption of cassava in Java is characterized by two factors. First, if the rice and corn harvest fails due to drought or other disasters, then the consumption of cassava will increase. On the other hand, if the rice and corn harvest are abundant, then the consumption of cassava will decrease [12]. Secondly, the rise in prices of major food crops, such as rice, will encourage the increase of consumption of cassava among the population. This indirectly leads to a rise in the price of cassava compared to before. Java island's residents generally consume cassava in the form of dried cassava or original cassava. A report from an agricultural consultant stated that at Kedu, Semarang, Malang and Vorstenlanden residences, cassava is processed into gaplek. The food products are then consumed by themselves [12]. In this case, cassava is used as food by the population in the event of a long dry season when the price of rice rises.

\section{Conclusion}

Cassava is an ambiguous plant during the colonial period on Java island. This is because cassava not only acts as a food crop but also a trading plant. Cassava is initially used as a trading plant, and it is cultivated in East Sumatra. Cassava and its products are exported to Europe as liquor ingredients. However, the biggest benefit is that its role as an alternative food crop in Java island during the malaise period. Since then, cassava has grown as an alternative food crop. At the same time, cassava is also being exported overseas. Cassava is cultivated in Java island on dry land. This is in accordance with the character of the plant which can almost be planted in all types of soil. This condition is very beneficial for the development of cassava in Indonesia, especially in Java island.

Cassava, as a trading plant, is exported to various countries, starting from the United States, Japan, China, the United Kingdom, and several other European countries. Cassava on the international market is used for various purposes. For example, cassava is used as animal feed ingredients in Europe. Cassava in the United States is used for various purposes, starting from the wood processing industry and for food. In international trade, Indonesia occupies an important position as an exporter of cassava. This is due to the vast area of cassava cultivation in Indonesia which is far greater than in other countries.

\section{References}

[1]. Kartodirdjo, S. Suryo, D. History Plantation in Indonesia, Ekonmi Social Studies. Yogyakarta: Aditya Media, (1978).

[2]. Mubyarto.The Sugar Industry: From Estate to Smallholder Cane Production ", in Bulletin of Indonesian Economic Studies, Vol. XIII (2), July: 29-44, (1977),

[3]. van der Eng, Pierre, Agricultural Growth in Indonesia since 1880, Gronigen: Rijk Universiteit, (1993).

[4]. Booth, A. Agricultural Development in Indonesia. Sydney: Allen and Unwin, (1988). 
[5]. Padmo, Sugiyanto, The Cultivation of Vorstenlanden Tobacco in Surakarta Residency and Besuki Tobacco in Besuki Residency and Its Impact on the Peasant Economy and Society: 1860-1960. Yogyakarta: Aditya Media, (1994).

[6]. Suhartono, "The impact of the sugar industry on rural life, Klaten 1850-1900", in Sartono Kartodirdjo (ed), Papers of the Fourth Indonesian-Dutch History Conference, Yogyakarta 24-29 July 1983. Yogyakarta: Gadjah Mada University Pree, (1986).

[7]. Purwanto, Bambang, "Indonesian Rakyyat Economy, 1890'an-1940" in J. Th. Lindblad (ed), Historical Foundation of the Indonesian Economy. Yogyakarta: Student Library, (2002).

[8]. Roesmanto, J. Kakao: Socio-Economic Study. Yogyakarta: Aditya Media, (1991).

[9]. Soetrisno, L. \& R. Winahyu. Oil Palm: Socio-Economic Study. Yogyakarta: Aditya Media.

[10]. Spillane, J. Its Role in Rubber Commodities in the Indonesian Economy. Yogyakarta Kanisius (1989).

[11]. Rinardi, Haryono. Political Cassava Era Colonial. Semarang: Messias, (2002).

[12]. Economisch Weekblad 1933,1935, 1937, 1938, 1939, 1940, and 1940.

[13]. Indisch Verslag II: Statistich Jaaroverzicht van Nederlandsch Indie over het Jaar 1931 , 1932, 1938, and 1939.

[14]. Gonggrijp, G., Schets Eener Ekonomische Geschiedenis van Nederlandsch-Indie. Haarlem: de Erven F. Bohn, (1928). 